\title{
Grazing impact of the invasive clam Corbula amurensis on the microplankton assemblage of the northern San Francisco Estuary
}

\author{
Valerie E. Greene ${ }^{1,2, *}$, Lindsay J. Sullivan ${ }^{1}$, Janet K. Thompson ${ }^{2}$, Wim J. Kimmerer ${ }^{1}$ \\ ${ }^{1}$ Romberg Tiburon Center for Environmental Studies, San Francisco State University, Tiburon, California 94920, USA \\ ${ }^{2}$ U.S. Geological Survey, Menlo Park, California 94025, USA
}

\begin{abstract}
Grazing by the overbite clam Corbula amurensis (formerly known as Potamocorbula) may be the cause of substantial declines in phytoplankton biomass and zooplankton in the San Francisco Estuary (SFE) following its introduction in 1986. While grazing rates have been examined on bacteria, phytoplankton, and copepod nauplii, the consumption of protistan microzooplankton by $C$. amurensis has not previously been measured. In this study, laboratory feeding experiments revealed that C. amurensis cleared $0.5 \mathrm{lind}^{-1} \mathrm{~h}^{-1}$ of microzooplankton (ciliates) and $0.2 \mathrm{lind}^{-1} \mathrm{~h}^{-1}$ of chlorophyll (chl) a. Despite the higher clearance rate on microzooplankton, clams obtained more of their carbon from phytoplankton, which dominated the prey assemblage on most dates. When the measured clearance rates are extrapolated to field populations of clams, fractional loss rates (50 to $90 \% \mathrm{~d}^{-1}$ ) exceed the population growth capacity of microzooplankton. Although microzooplankton may not be a major component of the diet of these clams, C. amurensis may further alter food web dynamics through consumption of this important trophic intermediary, thus disrupting this link from bacteria and phytoplankton to higher trophic levels.
\end{abstract}

KEY WORDS: Bivalves - Benthic-pelagic coupling - Microzooplankton - Microphytoplankton · Low-salinity zone $\cdot$ Ciliates

\section{INTRODUCTION}

Benthic-pelagic coupling is a key process in shallow estuaries (Dame et al. 1980, Cloern 1982, Nichols et al. 1990) that links food web dynamics in several ways. Tidal or wind-driven mixing re-suspends nutrients from the benthos, stimulating bacterial and phytoplankton production in the water column. This production may be filtered directly from the water column by zooplankton and benthic grazers or can sink to the bottom to fuel benthic communities. Grazing by filterfeeding bivalves on phytoplankton, as well as on other pelagic organic particles including zooplankton and bacteria, has been described for freshwater clams (Vaughn \& Hakenkamp 2001), freshwater mussels (MacIsaac et al. 1999), estuarine clams (Werner \& Hollibaugh 1993), marine mussels (Noren et al. 1999,
Davenport et al. 2000), oysters (Riisgard 1988, Baldwin \& Newell 1991), and scallops (Lehane \& Davenport 2002). By consuming phytoplankton, these bivalves divert resources from the water column to the sediments (Dame 1996) which depresses pelagic production. Control of phytoplankton biomass in the water column by both native and non-native bivalves has been reported to exert substantial influence on pelagic food webs (Cloern 1982, Officer et al. 1982, Miehls et al. 2009).

The clam Corbula amurensis (Family Corbulidae, formerly known as Potamocorbula amurensis; Coan 2002) was first discovered in Grizzly Bay (Fig. 1) in October 1986 and has persisted in the northern San Francisco Estuary (SFE) at densities exceeding $10000 \mathrm{~m}^{-2}$ (Carlton et al. 1990). C. amurensis can burrow into most sediment and has the ability to withstand a wide range of 


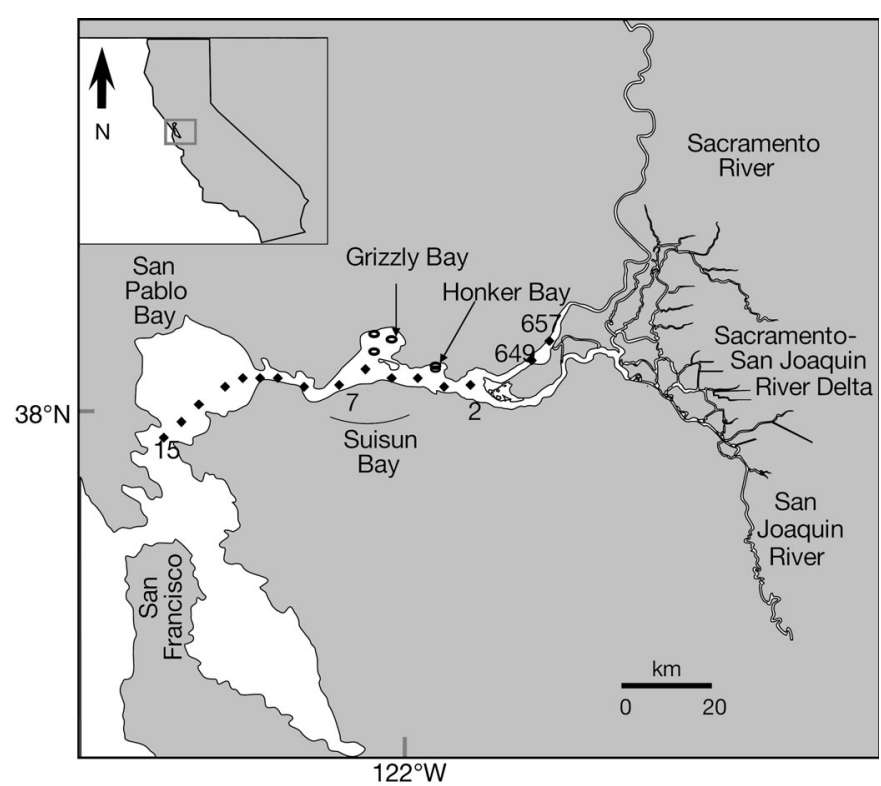

Fig. 1. The San Francisco Estuary. Solid black diamonds indicate US Geological Survey Water Quality Sampling Stations 2 to 15,649 and 657, sampled for microplankton abundance from February 2008 to February 2009. Eight benthic stations were sampled monthly; not all stations were sampled on all dates. The 4 channel stations were adjacent to Water Quality Stations 2, 4, 6, and 8 . The 4 shoal stations $(408,415,417$, and 433; represented by open circles) were located in Suisun Bay, Grizzly Bay and Honker Bay

salinities ( 2 to 30, Nicolini \& Penry 2000). As a result, C. amurensis can maintain high abundance year round in the northern SFE (Nichols et al. 1990) with peak abundance occurring in late summer (Thompson 2005).

Following the introduction of Corbula amurensis to the SFE, phytoplankton biomass in Suisun Bay (Fig. 1) dropped from a summer average of $>20$ to $<2 \mathrm{mg}$ chl a $\mathrm{m}^{-3}$ (Alpine \& Cloern 1992, Jassby et al. 2002). This decline of phytoplankton biomass has been correlated with long-term declines of copepod and mysid shrimp populations (Orsi \& Mecum 1996, Kimmerer 2006). The decline of several species of calanoid copepods was attributed to a combination of competition for food and direct consumption of copepod nauplii by clams (Kimmerer et al. 1994, Kimmerer 2006). Changes in the abundance of zooplankton and mysid shrimp (Orsi \& Mecum 1996, Kimmerer 2006) have been further linked to declines in planktivorous fish (Feyrer et al. 2003, Sommer et al. 2007) including the endangered delta smelt Hypomesus transpacificus, threatened longfin smelt Spirinchus thaleichthys, threadfin shad Dorosoma petenense, and striped bass Morone saxatilis. Similarly, the decline of the northern anchovy Engraulis mordax in San Pablo and Suisun Bays may have been due to a behavioral response to the declines in phytoplankton and zooplankton (Kimmerer 2006).
Corbula amurensis grazing rates have been estimated in the SFE for bacterioplankton (Werner \& Hollibaugh 1993), phytoplankton (Cole et al. 1992; Werner \& Hollibaugh 1993), and copepod nauplii (Kimmerer et al. 1994). These studies have used measured clearance rates to estimate potential impact of clams on prey populations. However, nothing is known about consumption by $C$. amurensis of protistan microzooplankton (20 to $200 \mu \mathrm{m})$, including ciliates and heterotrophic flagellates. Microzooplankton are key components of pelagic food webs as they remineralize organic matter and nutrients (Goldman \& Caron 1985, Goldman et al. 1985). Grazing microzooplankton can control the biomass of bacteria and phytoplankton (Fenchel 1982, McManus \& Fuhrman 1988, York at al. 2010), and are in turn a main food source for mesozooplankton (Bouley \& Kimmerer 2006, Gifford et al. 2007). Thus, microplankton are important trophic intermediaries between the microbial loop and the rest of the food web.

Our aim here is to understand the role of bivalve grazing on microplankton population dynamics and function in the aquatic food web. We quantified the abundance of microplankton, including both autotrophs and heterotrophs, during February 2008 to February 2009 in the northern SFE. We estimated clearance rates of Corbula amurensis on the microplankton community in the low-salinity zone (LSZ) and used $C$. amurensis biomass to estimate the potential impact of clam grazing on microplankton assemblages.

\section{MATERIALS AND METHODS}

Study area. The northern SFE includes the bays between the Sacramento-San Joaquin River Delta and central San Francisco Bay (Fig. 1). The focus for this study was in the LSZ, defined here to include salinities of 0.5 to 6 (Kimmerer 2004), usually located in Suisun Bay or the western Delta. This salinity range is summer-fall habitat for the threatened (federal) and endangered (state) delta smelt (Bennett 2005). It is turbid, well mixed, and has a bimodal depth distribution that includes extensive shoals $(2 \mathrm{~m})$ and deep channels (>10 m).

Field abundance. Samples were collected from R/V 'Polaris' in conjunction with the US Geological Survey (USGS) Water Quality Program which samples at fixed stations throughout the SFE (Fig. 1; http://sfbay.wr. usgs.gov/access/wqdata/). Microplankton were sampled monthly from February 2008 to February 2009 at Stations 2-15, 649, and 657 (Fig. 1); however, only samples from the LSZ were analyzed (Table 1). Salinity and temperature data were collected at each water quality sampling station using a submersible instru- 
ment package (Sea-Bird 9plus CTD). We collected water samples using a $20 \mathrm{l}$ bucket (surface) and a Niskin bottle ( 1 $\mathrm{m}$ from the bottom). Samples were preserved by gently filling a $250 \mathrm{ml}$ HDPE Nalgene ${ }^{\circledR}$ bottle containing $25 \mathrm{ml}$ of acid Lugol's solution (10\% final conc., vol/vol, Throndsen 1978).

Samples were stored for at least $48 \mathrm{~h}$ before processing to allow for complete fixation. Then each bottle was inverted a minimum of 50 times to ensure that the contents were homogenous and a $50 \mathrm{ml}$ subsample was removed and settled for $24 \mathrm{~h}$ (Claessens \& Prast 2008). The subsamples were then transferred to Utermöhl chambers (Lund et al. 1958) and microplankton were identified and counted with a Wild M40 inverted microscope at $100 \times$ magnification. A volume containing a minimum of 100 to 200 of the most abundant organisms was processed for each sample. Biovolume was estimated for representative cells of different shapes within each sampling period using measured lengths and widths. We calculated carbon biomass for each prey type using published relationships of volume to carbon. Aloricate ciliate carbon was calculated using the carbon:volume of $0.19 \pm 0.01$ (95\% CL, confidence limits) pg $\mu^{-3}$ (Putt \& Stoecker 1989) and adjusted for shrinkage during preservation (Stoecker et al. 1994). Tintinnid ciliate carbon was calculated

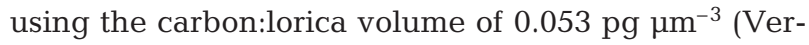
ity \& Langdon 1984). Diatom carbon was calculated using the algorithm pg $\mathrm{C}$ cell $^{-1}=0.216$ volume $^{0.939}$ (Menden-Deuer \& Lessard 2000). Carbon content of copepod nauplii was estimated using carbon measurements for Limnoithona tetraspina (Gould \& Kimmerer 2010). Counts and biomass from surface and bottom samples were averaged.

Feeding experiments. Clam feeding rates were quantified through disappearance of prey in incubation experiments. Six experiments were completed on board the R/V 'Polaris', once per month from July to

Table 1. Microplankton abundance survey. Stations sampled in the low-salinity zone of the northern San Francisco Estuary

\begin{tabular}{|lcc|}
\hline Date & Stations in low-salinity zone & Salinity range \\
\hline 12 Feb 08 & $2-10$ & $0.15-3.7$ \\
11 Mar 08 & $2-9$ & $0.16-5.5$ \\
6 May 08 & $2-6$ & $0.54-5.4$ \\
17 Jun 08 & $2-5,649$ & $0.5-4.7$ \\
15 Jul 08 & $2-3,649,657$ & $1.9-5.7$ \\
19 Aug 08 & $2-4,649,657$ & $0.09-5.7$ \\
16 Sep 08 & $2,649,657$ & $0.16-4.7$ \\
15 Oct 08 & $649-657$ & $0.5-6.4$ \\
19 Nov 08 & $2,649,657$ & $0.11-3.9$ \\
16 Dec 08 & $649-657$ & $0.3-5.7$ \\
13 Jan 09 & $2,649,657$ & $0.25-5.9$ \\
10 Feb 09 & $2-3,649,657$ & $0.15-4.7$ \\
\hline
\end{tabular}

Table 2. Corbula amurensis feeding experiments. Experimental conditions and mean clam length and ash-free dry weight (AFDW)

\begin{tabular}{|lrrccc|}
\hline $\begin{array}{l}\text { Expt. Date } \\
\text { no. }\end{array}$ & $\begin{array}{r}\text { Temp. } \\
\left({ }^{\circ} \mathrm{C}\right)\end{array}$ & & Salinity & $\begin{array}{c}\text { Mean } \\
\text { length }(\mathrm{mm})\end{array}$ & $\begin{array}{c}\text { Mean weight } \\
(\mathrm{g} \text { AFDW })\end{array}$ \\
\hline 1 & 16 Jul 08 & 20.6 & 4.3 & 10.8 & 0.0061 \\
2 & 20 Aug 08 & 20.4 & 5 & 13.8 & 0.0185 \\
3 & 17 Sep 08 & 18.7 & 4.1 & 14.5 & 0.0201 \\
4 & 16 Oct 08 & 16.9 & 4.8 & 15.0 & 0.0183 \\
5 & 18 Nov 08 & 15.3 & 3 & 14.7 & 0.0170 \\
6 & 17 Dec 08 & 9.6 & 3.4 & 13.2 & 0.0159 \\
\hline
\end{tabular}

December 2008 (Table 2). Clams and microplankton used in feeding experiments were collected from USGS benthic Station 2.1 (adjacent to Water Quality Station 2, Fig. 1). To ensure normal feeding, clams used in our experiments were collected immediately before incubations with a $0.05 \mathrm{~m}^{2}$ Van Veen grab. Six clams were chosen at random from the grab sample and shell lengths were measured to the closest millimeter with calipers. Only clams with no visible epiphytes were used in experiments. All experiments were conducted at in situ temperature and salinity (Table 2) under low light $\left(0.0015 \mu \mathrm{mol} \mathrm{m} \mathrm{m}^{-2} \mathrm{~s}^{-1}\right)$. Light levels were measured using a LI-COR Model LI-1400 Data logger with an LI-192SA Underwater Quantum Sensor.

In situ surface water containing the microplankton assemblage was collected with a 201 bucket and poured gently through a $200 \mu \mathrm{m}$ mesh screen to remove larger zooplankton. Nine 41 Camwear ${ }^{\circledR}$ clear plastic containers were filled with $3 \mathrm{l}$ of the in situ microplankton assemblage. Magnetic stir bars rotating at low speed kept the natural prey assemblage well mixed in experimental and control containers. Experimental duration $(4 \mathrm{~h})$ was estimated from preliminary experiments to ensure that clams did not clear more than $60 \%$ of the assemblage to avoid changes in feeding rate in response to decreases in food concentration. One clam was placed into a suspended tray filled with sand and 1 tray was suspended at the midpoint of each of 6 experimental containers (Werner \& Hollibaugh 1993). Each experimental period began when $50 \%$ of the clams had buried themselves, opened their valves, and extended their siphons, at which point they were assumed to be filtering ( 15 $\mathrm{min})$. Three control containers with trays and sand but no clams accounted for growth or mortality of the prey assemblage not related to clam feeding.

Three $250 \mathrm{ml}$ initial samples were taken immediately after size fractionating the entire water sample and preserved with $10 \%$ acid Lugol's solution to determine the initial in situ assemblage. Experiments were run for $4 \mathrm{~h}$, after which a $250 \mathrm{ml}$ sample was taken from 
each control and experimental container and preserved in the same way as the initial samples. Samples were analyzed as described for the field abundance.

Chl a concentrations in experimental and control treatments were determined at $t=0$ and $t=4 \mathrm{~h}$. Samples $(250 \mathrm{ml})$ were filtered onto $47 \mathrm{~mm}$ Whatman GF/F filters and extracted with $90 \%$ acetone. Chl a concentration was determined using a Turner Designs Model 10 Fluorometer.

Clam biomass. Clam biomass was measured from February 2008 through February 2009 at 4 channel stations (mean depth $=10 \mathrm{~m}$ ) adjacent to water quality Stns 2, 4, 6, and 8; and 4 shoal stations (mean depth $=2$ $\mathrm{m}$ ) in Suisun Bay, Grizzly Bay and Honker Bay (Fig. 1). Three benthic samples were taken from each station from February 2008 to September 2008, and 1 sample per station was taken from October 2008 to February 2009. Samples were fixed in $10 \%$ buffered formalin, then preserved in $70 \%$ ethyl alcohol, and all bivalves were measured and counted. A subset of clams was measured, dried at $60^{\circ} \mathrm{C}$, weighed (dry weight, DW), combusted at $500^{\circ} \mathrm{C}$, and re-weighed (ash weight, AW); ash-free-dry weight (AFDW) was determined by difference (Crisp 1971). Length-weight regressions were determined monthly (ln AFDW $=a(\ln$ length) $-b$ ) and used to estimate bivalve biomass at each station.

We calculated ingestion rates at all water-quality monitoring stations in the LSZ as the product of prey biomass and the mean clearance rate. Additionally, clam biomass $\left(\mathrm{g} \mathrm{m}^{-2}\right)$ was multiplied by weight-specific clearance rates $\left(\mathrm{l} \mathrm{g}^{-1} \mathrm{~h}^{-1}\right)$ to estimate community clearance rate $\left(\mathrm{m}^{-2} \mathrm{~d}^{-1}\right)$ which was divided by depth to calculate the daily fractional loss of prey $\left(\mathrm{d}^{-1}\right)$ due to grazing by clams.

Data analysis. Clearance rates were calculated as (Frost 1972):

$$
g_{i}=\ln \left(N_{\mathrm{c}} / N_{i}\right) V / t
$$

where $g_{i}$ is clearance rate for a single clam $\left(\mathrm{l} \mathrm{h}^{-1}\right), N_{i}$ is the number of cells per liter of a given taxon counted in experimental sample $i, N_{\mathrm{c}}$ is the mean number of cells per liter counted in the corresponding controls, $V$ is the volume of the experimental containers (l), and $t$ is the incubation duration (h). This model assumes constant grazing and growth in the sample containers, and that the specific growth rate of microplankton in experimental containers was the same as that in the controls. All taxon combinations in each experiment were included if there were no zero abundances in the controls, mean abundance of controls $\left(N_{\mathrm{c}}\right)$ was at least 5 , and no more than 2 zeros occurred in the experimental samples. This resulted in 29 experiment/taxon combinations in all 6 experiments.

The above model was fit to the count data using Bayesian hierarchical models (Lunn et al. 2000) with a
Poisson error distribution under the assumption that subsampling was random. This results in decreasing uncertainty as the number of cells counted increases. Using Bayesian models allowed us to incorporate subsampling error and to readily determine differences in clearance rate among prey taxa and experiments. The Bayesian models were fit using WinBUGS 1.4.3 (Lunn et al. 2000) with triplicate Markov chains. Each chain was thinned 10 -fold to reduce autocorrelation, and 10000 samples were retained after the first 1000 samples were discarded to remove effects of initial values. Monte Carlo standard errors of the mean were much smaller than the standard deviations of the parameter estimates, also indicating good model performance. Gelman-Rubin statistics (Gelman et al. 2004) and plots of autocorrelation and time series of simulations demonstrated convergence of the model.

Prior distributions for grazing rates were uninformative and were normally distributed with a mean of 0 and a standard deviation of 10 . These distributions were flat over the range of the results and therefore had no influence on the model results. Control means had normal prior distributions with a standard deviation of 1000 , truncated to $>0$, which were also flat enough to have negligible influence on the results.

\section{RESULTS}

\section{Field abundance}

Diatoms were the numerically dominant microphytoplankton across all months sampled (Fig. 2). Total microphytoplankton abundances were higher than those of total microzooplankton, except in early spring. A bloom of Nitzschia sp. (unidentified pennate diatoms) was observed in late summer and a bloom of benthic pennate diatoms, mostly Entomoneis sp., occurred in winter. Aloricate and tintinnid (= loricate; i.e. Codonellopsis sp.) ciliates were the most abundant microzooplankton in all months. Myrionecta rubra (= Mesodinium rubrum), an aloricate ciliate, was present in every month sampled ( $=1100 \mathrm{l}^{-1}$, range 160 to $4690 \mathrm{l}^{-1}$ ) with the highest abundance in May. Tintinnid ciliate abundance $\left(=940 \mathrm{l}^{-1}\right.$, range 100 to $1200 \mathrm{l}^{-1}$ ) was usually less than aloricate ciliate abundance. Copepod nauplii, some identified as Limnoithona tetraspina nauplii, were also present in every month, except February 2009. No dinoflagellates $(>20 \mu \mathrm{m})$ were observed in our counts.

\section{Feeding experiments}

Ten prey taxa were abundant enough to count during the 6 feeding experiments (Table 3). Microphyto- 


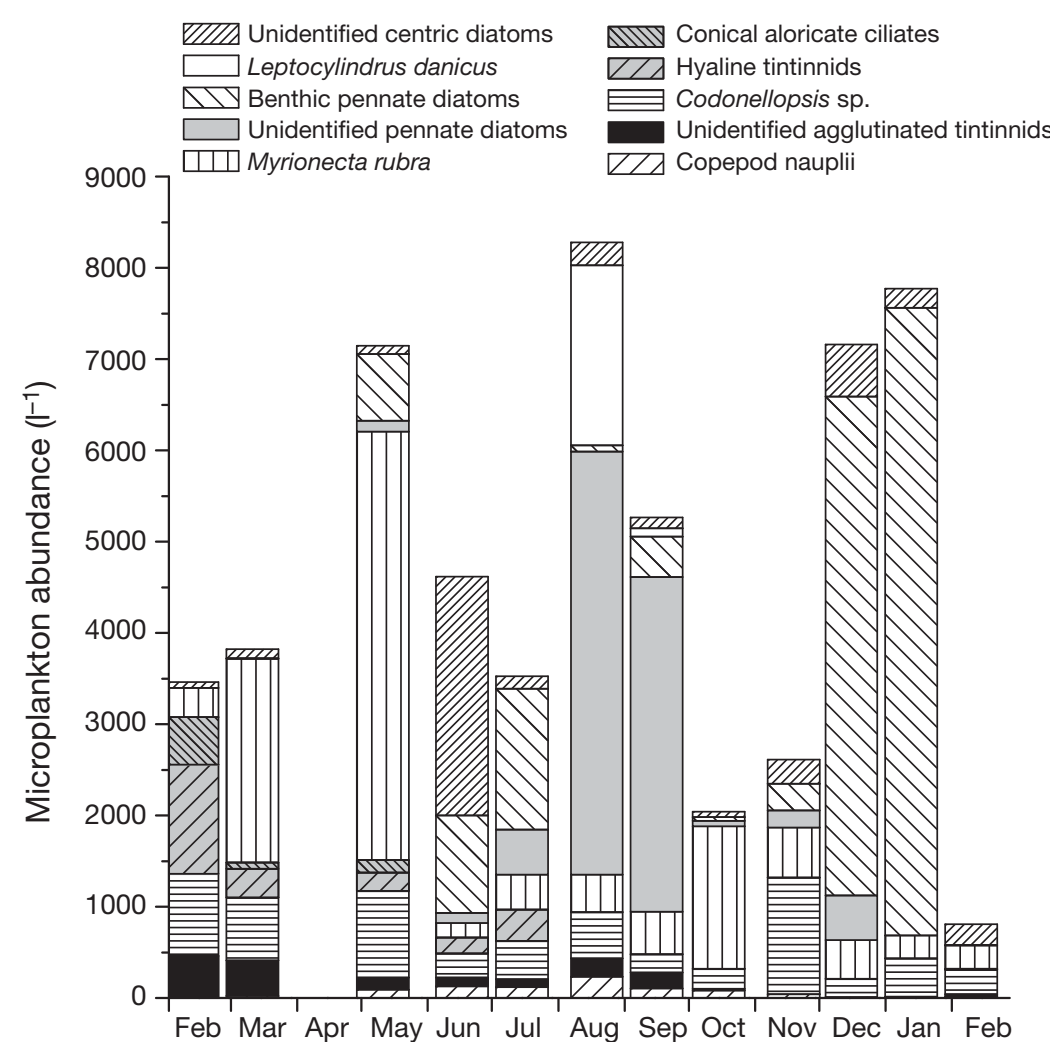

Fig. 2. Monthly abundance of microplankton in the low-salinity zone of the northern San Francisco Estuary from February 2008 to February 2009, averaged among stations

plankton were the most abundant in all experiments. Four categories of microphytoplankton were observed: unidentified centric diatoms, Leptocylindrus danicus (a chain-forming centric diatom), benthic pennate diatoms (including Entomoneis sp.), and unidentified pen- nate diatoms (most of which were Nitzschia spp.). The remaining 6 categories were microzooplankton: aloricate ciliates (Myrionecta rubra and conical ciliates), tintinnid ciliates (hyaline and agglutinated, including Codonellopsis sp.), and copepod nauplii. The copepod nauplii were the size of Limnoithona tetraspina nauplii but were not identified in all experiments. Only M. rubra and Codonellopsis sp. were observed in every experiment. Diatom and ciliate populations were sometimes lower in the control treatments than in the initial samples, indicating a decrease over the $4 \mathrm{~h}$ experimental duration, presumably from grazing by mesozooplankton not removed by the $200 \mu \mathrm{m}$ size fractionation prior to incubations.

Prey biomass (Table 4) was dominated by copepod nauplii $\left(\sim 34 \mu \mathrm{g} \mathrm{Cl}^{-1}\right)$. Ciliates

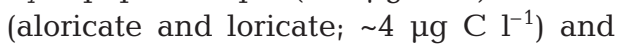

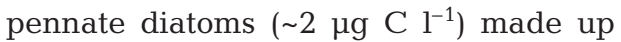
most of the remainder, and centric diatoms contributed a negligible amount to the total prey biomass.

Clearance rates on individual microplankton taxa (Table 5) ranged from -0.6 to $1.1 \mathrm{lind}^{-1} \mathrm{~h}^{-1}$. The highest mean rates in all experiments on microphytoplankton ( 0.7 to 0.81 ind $\left.^{-1} \mathrm{~h}^{-1}\right)$ were on the 'unidentified pennate diatoms' and 'benthic pennate diatoms'. The lowest rates were on copepod nauplii $\left(=0.11 \mathrm{ind}^{-1} \mathrm{~h}^{-1}\right)$ and confidence limits included zero in every experiment. Rates on 'unidentified centric diatoms' were the most

Table 3. Corbula amurensis feeding experiments. Mean abundance of microplankton (number $\mathrm{l}^{-1} \pm 95 \%$ CL) in initial samples (upper section) and final control samples (lower section). -: experiment/taxon combinations that did not meet criteria to be included in the calculations (see 'Materials and methods'). Microzooplankton are indicated in bold

\begin{tabular}{|c|c|c|c|c|c|c|c|c|c|c|}
\hline $\begin{array}{l}\text { Expt. } \\
\text { no. }\end{array}$ & $\begin{array}{c}\text { Unidentified } \\
\text { centric } \\
\text { diatoms }\end{array}$ & $\begin{array}{l}\text { Lepto- } \\
\text { cylindrus } \\
\text { danicus }\end{array}$ & $\begin{array}{l}\text { Benthic } \\
\text { pennate } \\
\text { diatoms }\end{array}$ & $\begin{array}{l}\text { Unidentified } \\
\text { pennate } \\
\text { diatoms }\end{array}$ & $\begin{array}{c}\text { Myrionecta } \\
\text { rubra }\end{array}$ & $\begin{array}{c}\text { Conical } \\
\text { aloricate } \\
\text { ciliates }\end{array}$ & $\begin{array}{l}\text { Hyaline } \\
\text { tintinnids }\end{array}$ & $\begin{array}{l}\text { Codonel- } \\
\text { lopsis sp. }\end{array}$ & $\begin{array}{l}\text { Unidentified } \\
\text { agglutinated } \\
\text { tintinnids }\end{array}$ & $\begin{array}{c}\text { Copepod } \\
\text { nauplii }\end{array}$ \\
\hline \multicolumn{11}{|c|}{ Initial no. $\mathrm{l}^{-1}$} \\
\hline 1 & $864 \pm 218$ & - & - & - & $489 \pm 89$ & $333 \pm 62$ & $504 \pm 268$ & $603 \pm 146$ & $93 \pm 24$ & $285 \pm 36$ \\
\hline 2 & $390 \pm 123$ & $1149 \pm 187$ & $36 \pm 23$ & $7581 \pm 875$ & $435 \pm 131$ & - & - & $204 \pm 90$ & $495 \pm 84$ & $195 \pm 150$ \\
\hline 3 & $126 \pm 76$ & $84 \pm 53$ & - & $9747 \pm 969$ & $156 \pm 36$ & - & - & $132 \pm 64$ & $504 \pm 118$ & $207 \pm 81$ \\
\hline 4 & $228 \pm 48$ & - & - & $696 \pm 150$ & $1152 \pm 352$ & - & - & $288 \pm 140$ & $24 \pm 27$ & $144 \pm 323$ \\
\hline 5 & - & - & $1104 \pm 27$ & $432 \pm 186$ & $336 \pm 71$ & - & - & $528 \pm 27$ & - & $12 \pm 54$ \\
\hline 6 & $192 \pm 54$ & - & $20904 \pm 2198$ & $360 \pm 186$ & $204 \pm 117$ & - & - & $168 \pm 54$ & - & - \\
\hline \multicolumn{11}{|c|}{ Final no. $1^{-1}$} \\
\hline 1 & $606 \pm 238$ & - & - & $12 \pm 6$ & $483 \pm 236$ & $474 \pm 74$ & $411 \pm 37$ & $342 \pm 104$ & $108 \pm 23$ & $261 \pm 160$ \\
\hline 2 & $441 \pm 35$ & $1299 \pm 169$ & - & $10290 \pm 885$ & $122 \pm 158$ & - & - & $204 \pm 54$ & $546 \pm 60$ & $306 \pm 12$ \\
\hline 3 & $51 \pm 36$ & $48 \pm 24$ & - & $10266 \pm 684$ & $60 \pm 78$ & - & - & $24 \pm 24$ & $453 \pm 55$ & $177 \pm 24$ \\
\hline 4 & $150 \pm 75$ & - & - & $720 \pm 81$ & $888 \pm 210$ & - & - & $156 \pm 117$ & $60 \pm 27$ & $33 \pm 29$ \\
\hline 5 & - & - & $1380 \pm 142$ & $384 \pm 220$ & $144 \pm 47$ & - & - & $336 \pm 117$ & - & - \\
\hline 6 & $60 \pm 27$ & - & $11916 \pm 1556$ & - & $216 \pm 123$ & - & - & $60 \pm 27$ & - & - \\
\hline
\end{tabular}


Table 4. Corbula amurensis feeding experiments. Mean biomass of microplankton ( $\mu \mathrm{g} \mathrm{C} \mathrm{l}^{-1} \pm 95 \%$ CL) in initial control samples. -: experiment/taxon combinations that did not meet criteria to be included in the calculations (see 'Materials and methods'). Microzooplankton are indicated in bold

\begin{tabular}{|c|c|c|c|c|c|c|c|c|c|c|c|}
\hline $\begin{array}{l}\text { Expt. } \\
\text { no. }\end{array}$ & $\begin{array}{l}\text { Unidentified } \\
\text { centric } \\
\text { diatoms }\end{array}$ & $\begin{array}{l}\text { Lepto- } \\
\text { cylindrus } \\
\text { danicus }\end{array}$ & $\begin{array}{l}\text { Benthic } \\
\text { pennate } \\
\text { diatoms }\end{array}$ & $\begin{array}{l}\text { Unidentified } \\
\text { pennate } \\
\text { diatoms }\end{array}$ & $\begin{array}{l}\text { Myrio- } \\
\text { necta } \\
\text { rubra }\end{array}$ & $\begin{array}{c}\text { Conical } \\
\text { aloricate } \\
\text { ciliates }\end{array}$ & $\begin{array}{l}\text { Hyaline } \\
\text { tintinnids }\end{array}$ & $\begin{array}{l}\text { Codonel- } \\
\text { lopsis } \\
\text { sp. }\end{array}$ & $\begin{array}{l}\text { Unidentified } \\
\text { agglutinated } \\
\text { tintinnids }\end{array}$ & $\begin{array}{l}\text { Copepod } \\
\text { nauplii }\end{array}$ & $\begin{array}{l}\text { Total micro- } \\
\text { zooplankton } \\
\text { carbon }\end{array}$ \\
\hline 1 & $0.06 \pm 0.01$ & - & - & - & $3.6 \pm 0.7$ & $0.31 \pm 0.06$ & $0.38 \pm 0.20$ & $0.60 \pm 0.15$ & $0.07 \pm 0.02$ & $57.0 \pm 7.2$ & 61.96 \\
\hline 2 & $0.03 \pm 0.01$ & $0.005 \pm 0.004$ & $0.04 \pm 0.007$ & $4.5 \pm 0.52$ & $3.2 \pm 1.0$ & - & - & $0.20 \pm 0.09$ & $0.39 \pm 0.07$ & $39.0 \pm 30.0$ & 42.79 \\
\hline 3 & $0.01 \pm 0.005$ & - & $0.003 \pm 0.002$ & $\begin{array}{ll}2 & 5.9 \pm 0.58\end{array}$ & $1.1 \pm 0.3$ & - & - & $0.13 \pm 0.06$ & $0.39 \pm 0.09$ & $41.4 \pm 16.1$ & 43.02 \\
\hline 4 & $0.01 \pm 0.003$ & - & - & $0.42 \pm 0.09$ & $8.5 \pm 2.6$ & - & - & $0.29 \pm 0.14$ & $0.02 \pm 0.02$ & $28.8 \pm 64.5$ & 37.61 \\
\hline 5 & - & $0.17 \pm 0.004$ & - & $0.26 \pm 0.11$ & $2.8 \pm 0.5$ & - & - & $0.53 \pm 0.03$ & - & $2.4 \pm 10.8$ & 5.73 \\
\hline 6 & $0.01 \pm 0.004$ & $3.2 \pm 0.33$ & - & $0.04 \pm 0.02$ & $1.5 \pm 0.9$ & - & - & $0.17 \pm 0.05$ & - & - & 1.67 \\
\hline
\end{tabular}

variable over experiments. The mean clearance rate for each month on Myrionecta rubra was always greater than or equal to that on any group of tintinnid ciliates (Table 5). Mean clearance rates on microplankton (Table 5) showed no seasonal trends.

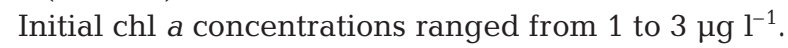
A reduction in chl a was observed in every experiment. Clearance rates on chl a ranged from 0.1 to 0.41 ind $^{-1}$ $\mathrm{h}^{-1}$, (Table 5). These rates were usually lower than rates on microzooplankton and, in most cases, on microphytoplankton (Table 5).

Ingestion of microzooplankton in the feeding experiments ranged from 10 to $240 \mu \mathrm{g} \mathrm{C}$ ind ${ }^{-1} \mathrm{~d}^{-1}$ (Table 6).
Copepod nauplii were not included in these totals because they were not present in every experiment and when present their numbers were low. However, when present, copepod nauplii comprised the largest fraction of microplankton carbon ingested by clams (Table 6), despite the much lower clearance rates than for total microzooplankton (Table 5).

\section{Population estimates}

Corbula amurensis populations had seasonal peaks in biomass in late summer (Fig. 3A). Biomass began to

Table 5. Corbula amurensis feeding experiments. Clam clearance rates ( $1 \mathrm{ind}^{-1} \mathrm{~h}^{-1} \pm 95 \% \mathrm{CL}$ ) on microplankton by experiment number and prey category. -: experiment/taxon combinations that did not meet criteria to be included in the calculations (see 'Materials and methods'). Microzooplankton are indicated in bold. MCR: mean clearance rate (microzooplankton excluding nauplii)

\begin{tabular}{|c|c|c|c|c|c|c|c|c|c|c|c|c|}
\hline $\begin{array}{l}\text { Expt. } \\
\text { no. }\end{array}$ & $\begin{array}{l}\text { Unidentified } \\
\text { centric } \\
\text { diatoms }\end{array}$ & $\begin{array}{l}\text { Lepto- } \\
\text { cylindrus } \\
\text { danicus }\end{array}$ & $\begin{array}{l}\text { Benthic } \\
\text { pennate } \\
\text { diatoms }\end{array}$ & $\begin{array}{l}\text { Unidentified } \\
\text { pennate } \\
\text { diatoms }\end{array}$ & $\begin{array}{l}\text { Myrio- } \\
\text { necta } \\
\text { rubra }\end{array}$ & $\begin{array}{c}\text { Conical } \\
\text { aloricate } \\
\text { ciliates }\end{array}$ & $\begin{array}{c}\text { Hyaline } \\
\text { tintinnids }\end{array}$ & $\begin{array}{l}\text { Codonel- } \\
\text { lopsis } \\
\text { sp. }\end{array}$ & $\begin{array}{l}\text { Unidentified } \\
\text { agglutinated } \\
\text { tintinnids }\end{array}$ & $\begin{array}{l}\text { Copepod } \\
\text { nauplii }\end{array}$ & MCR & $\begin{array}{l}\text { MCR } \\
\text { chl a }\end{array}$ \\
\hline 1 & $0.1 \pm 0.2$ & - & - & - & $0.6 \pm 0.2$ & $0.7 \pm 0.2$ & $0.3 \pm 0.2$ & $-0.05 \pm 0.2$ & $0.4 \pm 0.4$ & $0.01 \pm 0.3$ & $0.4 \pm 0.1$ & $0.1 \pm 0.1$ \\
\hline 2 & $0.8 \pm 0.2$ & $0.69 \pm 0.1$ & - & $0.8 \pm 0.04$ & $0.7 \pm 0.2$ & - & - & $0.5 \pm 0.3$ & $0.6 \pm 0.2$ & $0.2 \pm 0.2$ & $0.6 \pm 0.1$ & $0.4 \pm 0.1$ \\
\hline 3 & $-0.6 \pm 0.4$ & - & - & $0.4 \pm 0.03$ & $0.2 \pm 0.3$ & - & - & - & $0.2 \pm 0.2$ & $0.1 \pm 0.2$ & $0.2 \pm 0.1$ & $0.2 \pm 0.1$ \\
\hline 4 & $1.1 \pm 0.5$ & - & - & $1.0 \pm 0.2$ & $1.1 \pm 0.2$ & - & - & $0.7 \pm 0.4$ & - & - & $1.0 \pm 0.2$ & $0.3 \pm 0.2$ \\
\hline 5 & - & - & $0.9 \pm 0.2$ & $0.5 \pm 0.3$ & $0.7 \pm 0.5$ & - & - & $0.4 \pm 0.3$ & - & - & $0.5 \pm 0.2$ & $0.2 \pm 0.1$ \\
\hline 6 & - & - & $0.6 \pm 0.05$ & - & $0.6 \pm 0.3$ & - & - & & - & - & $0.6 \pm 0.3$ & $0.1 \pm 0.1$ \\
\hline
\end{tabular}

Table 6. Corbula amurensis feeding experiments. Mean clam ingestion rate on microplankton $\left(\mu \mathrm{C} \mathrm{C}^{\mathrm{ind}} \mathrm{d}^{-1} \pm 95 \% \mathrm{CL}\right)$. -: experiment/taxon combinations that did not meet criteria to be included in the calculations (see 'Materials and methods'). Microzooplankton are indicated in bold. TI: total ingestion of microzooplankton (excluding nauplii)

\begin{tabular}{|c|c|c|c|c|c|c|c|c|c|c|c|}
\hline $\begin{array}{l}\text { Expt. } \\
\text { no. }\end{array}$ & $\begin{array}{c}\text { Unidentified } \\
\text { centric } \\
\text { diatoms }\end{array}$ & $\begin{array}{l}\text { Lepto- } \\
\text { cylindrus } \\
\text { danicus }\end{array}$ & $\begin{array}{l}\text { Benthic } \\
\text { pennate } \\
\text { diatoms }\end{array}$ & $\begin{array}{l}\text { Unidentified } \\
\text { pennate } \\
\text { diatoms }\end{array}$ & $\begin{array}{c}\text { Myrio- } \\
\text { necta } \\
\text { rubra }\end{array}$ & $\begin{array}{c}\text { Conical } \\
\text { aloricate } \\
\text { ciliates }\end{array}$ & $\begin{array}{l}\text { Hyaline } \\
\text { tintinnids }\end{array}$ & $\begin{array}{l}\text { Codonel- } \\
\text { lopsis } \\
\text { sp. }\end{array}$ & $\begin{array}{l}\text { Unidentified } \\
\text { agglutinated } \\
\text { tintinnids }\end{array}$ & $\begin{array}{c}\text { Copepod } \\
\text { nauplii }\end{array}$ & TI \\
\hline 1 & $0.2 \pm 0.4$ & - & - & - & $61.0 \pm 31.0$ & $5.3 \pm 2.0$ & $3.0 \pm 2.0$ & $-0.5 \pm 3.0$ & $0.7 \pm 0.8$ & $52.0 \pm 326.0$ & 69.5 \\
\hline 2 & $0.3 \pm 0.2$ & $0.8 \pm 0.3$ & - & $89.0 \pm 17.0$ & $61.0 \pm 38.0$ & - & - & $2.8 \pm 1.1$ & $5.8 \pm 1.8$ & $296.0 \pm 391.0$ & 69.6 \\
\hline 3 & $-0.1 \pm 0.1$ & - & - & $56.0 \pm 25.0$ & $9.5 \pm 13.6$ & - & - & - & $2.3 \pm 2.5$ & $147.0 \pm 314.0$ & 10.5 \\
\hline 4 & $0.3 \pm 0.1$ & - & - & $10.5 \pm 4.2$ & $240.0 \pm 70.0$ & - & - & $4.3 \pm 2.1$ & - & - & 244.4 \\
\hline 5 & - & - & $4.0 \pm 1.0$ & $3.5 \pm 1.0$ & $31.0 \pm 28.0$ & - & - & $7.5 \pm 7.2$ & - & - & 38.5 \\
\hline 6 & - & - & $49.0 \pm 9.0$ & - & $23.0 \pm 7.0$ & - & - & - & - & - & 23.5 \\
\hline
\end{tabular}



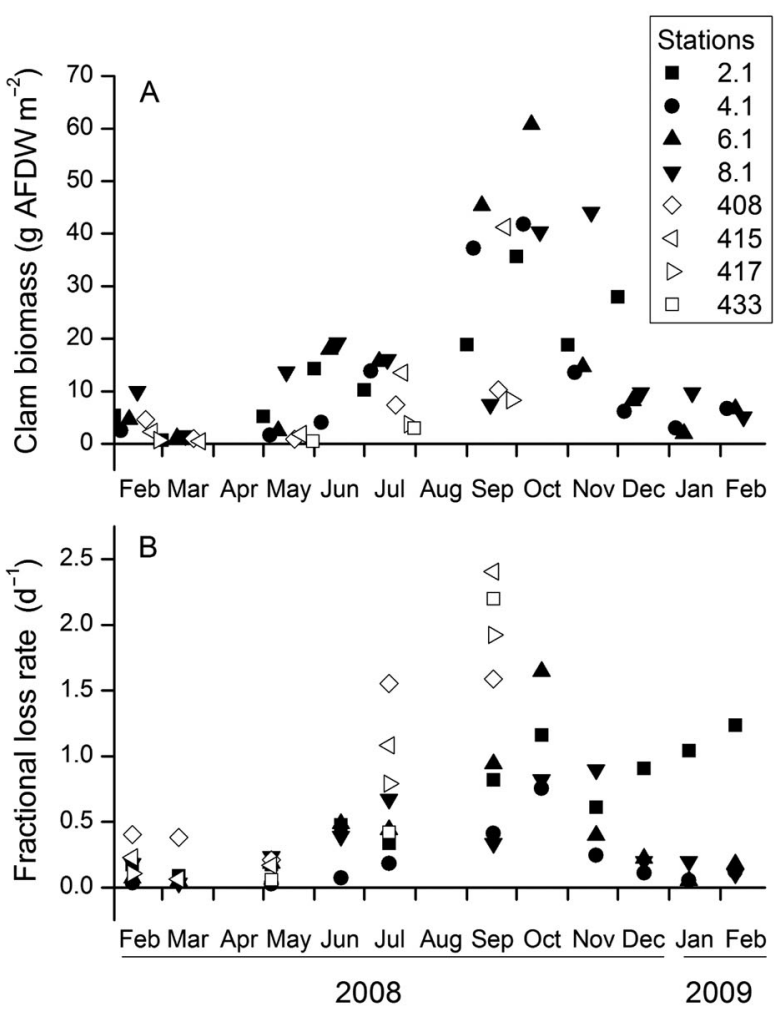

Fig. 3. Corbula amurensis. (A) Mean clam biomass from February 2008 to February 2009 in the low-salinity zone of the San Francisco Estuary. Stations 2.1, 4.1, 6.1 and 8.1 are adjacent to water quality stations $2,4,6$, and 8 , respectively. Points represent means of 3 replicates, except in June 2008 and October 2008 through February 2009 when only single grabs were taken. (B) Estimated fractional loss rate $\left(\mathrm{d}^{-1}\right)$ of microzooplankton resulting from grazing. In both panels, solid symbols indicate channel stations and open symbols indicate shoal stations

decline in the fall except at Stn 2.1 where it increased from October 2008 to February 2009. Clam biomass was always higher at the channel stations than at the shoal stations (Fig. 3A). C. amurensis cleared a mean of 20 to $50 \% \mathrm{~d}^{-1}$ of the microzooplankton from the water column in the channel and a mean of 80 to $90 \%$ $\mathrm{d}^{-1}$ in the shoals (Fig. 3B). Ingestion of microzooplankton increased as clam biomass increased in the late summer (Fig. 3). On most dates the ingestion of phytoplankton carbon was higher than ingestion of microzooplankton (Fig. 4). The mean ingestion rates of microzooplankton and phytoplankton $(=\mathrm{chl}$ a) by an individual Corbula amurensis varied in rough proportion to their respective standing stocks (Fig. 4).

\section{DISCUSSION}

This study reports the most comprehensive investigation of the clearance rates of bivalves on microzoo-

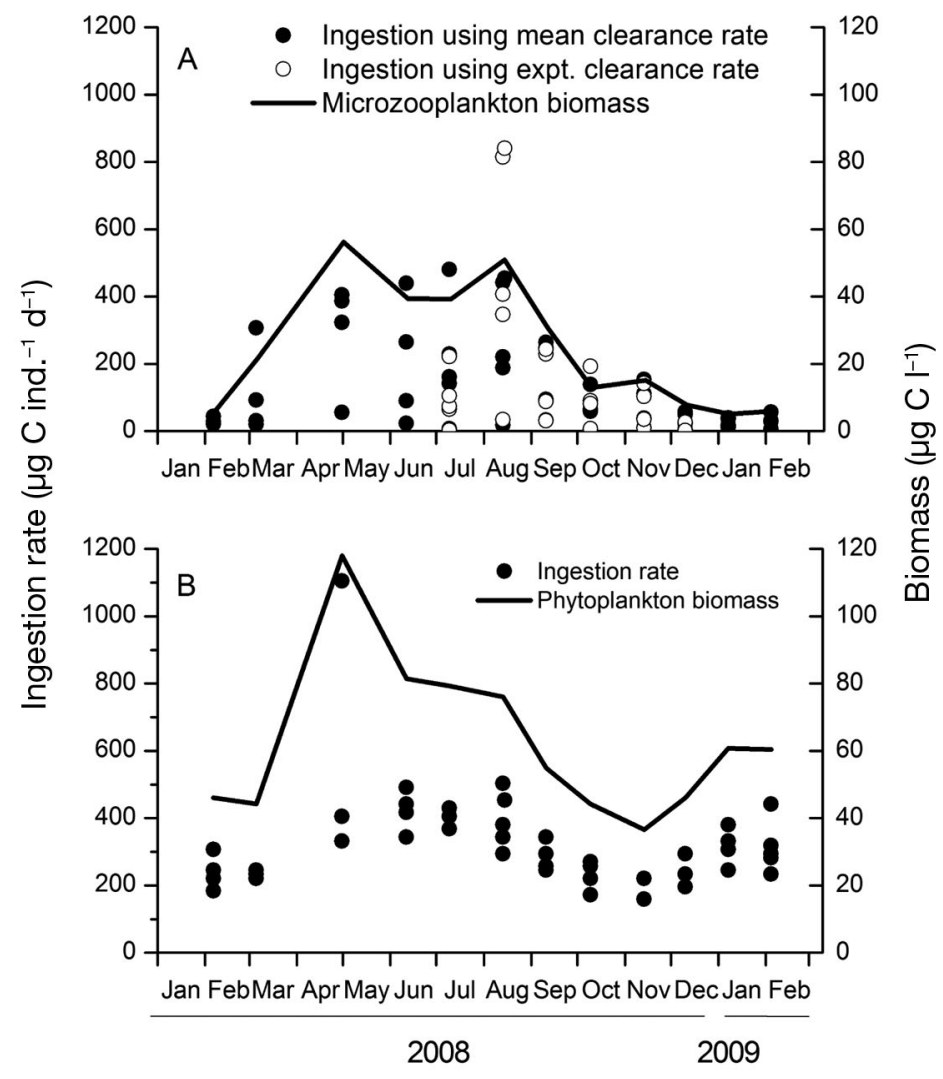

Fig. 4. Corbula amurensis. Ingestion by $C$. amurensis in the low salinity zone of the San Francisco Estuary from February 2008 to February 2009. (A) Ingestion by the clam was calculated using the overall mean calculated clearance rate for microzooplankton (solid circles) and the experimental (expt.) rate (open circles). The solid line represents mean standing stock ( $\mu \mathrm{g} \mathrm{C} \mathrm{l}^{-1}$ ) of microzooplankton on each date. (B) Ingestion of phytoplankton carbon by C. amurensis was calculated from chl $a$ and standing stock of phytoplankton for all stations in the low-salinity zone from February 2008 to February 2009. Closed circles indicate ingestion of chl $a$ and line shows the mean standing stock of phytoplankton carbon calculated from chl a (http://sfbay.wr.usgs.gov/access/wqdata/) on each date. Ingestion of phytoplankton carbon was calculated assuming a C:chl ratio of 23.6 (W.J. Kimmerer, A. Parker, U. Lidström unpubl.)

plankton and the first measurements of clearance rates of an estuarine bivalve on ciliates. Most of the previous studies on bivalve clearance rates have focused on microphytoplankton using chl $a$ as a proxy for all sizes of phytoplankton (e.g. Cole et al. 1992) and a few have examined other prey including bacterioplankton (e.g. Werner \& Hollibaugh 1993), rotifers (e.g. MacIsaac et al. 1999), and crustaceans (e.g. Kimmerer et al. 1994, Pace et al. 1998, Davenport et al. 2000). The range of clearance rates on microzooplankton observed in this study were larger and the maxima higher than clearance rates previously determined on chl $a$ and bacterioplankton (Table 7). However, microzooplankton provided a smaller portion of the clams' apparent 
Table 7. Corbula amurensis clearance rates

\begin{tabular}{|lcr|}
\hline Clearance rate & Prey category & \multicolumn{1}{c|}{ Source } \\
\hline $130-380 \mathrm{ml} \mathrm{ind}^{-1} \mathrm{~h}^{-1}$ & Chl a & This study \\
$110-1050 \mathrm{ml} \mathrm{ind}^{-1} \mathrm{~h}^{-1}$ & Microphytoplankton & \\
$170-970 \mathrm{ml} \mathrm{ind}^{-1} \mathrm{~h}^{-1}$ & Microzooplankton & \\
$154-337 \mathrm{ml} \mathrm{ind}^{-1} \mathrm{~h}^{-1}$ & Chl a & Werner \& Hollibaugh (1993) \\
$45 \mathrm{ml} \mathrm{ind}^{-1} \mathrm{~h}^{-1}$ & Bacterioplankton & \\
$3-200 \mathrm{ml} \mathrm{ind}^{-1} \mathrm{~h}^{-1}$ & Chl a & Cole et al. (1992) \\
$4 \times 10^{-3} \mathrm{lnd}^{-1} \mathrm{~h}^{-1}$ & Copepod nauplii & Kimmerer et al. (1994) \\
\hline
\end{tabular}

ingestion than phytoplankton measured as chl a (Fig. 4) due to the lower biomass of microzooplankton than phytoplankton during the sample period.

\section{Field abundance}

The microplankton abundances observed in this study were similar to those reported previously for the SFE. Ambler et al. (1985) quantified estuary-wide distribution and abundance of zooplankton, including tintinnids, rotifers, and copepod nauplii, from 1978 to 1981, prior to the introduction of Corbula amurensis. However, the 64- $\mu$ m mesh used in that study was most likely too large to capture small ciliates or they were not reported. Nevertheless, tintinnid ciliate abundances $(\geq 80 \mu \mathrm{m})$ reported by Ambler et al. (1985) were generally $>1000 \mathrm{l}^{-1}$ and occasionally as great as $10^{4} \mathrm{l}^{-1}$ to $10^{5} \mathrm{l}^{-1}$ in the northern SFE (Ambler et al. 1985). Ciliates larger than $64 \mu \mathrm{m}$ were rarely observed in the present study, and when present their abundances never exceeded $1000 \mathrm{l}^{-1}$ (Fig. 2, unidentified agglutinated tintinnids).

Other, less spatially and temporally extensive studies (Rollwagen-Bollens et al. 2006, Gifford et al. 2007) conducted after the spread of Corbula amurensis have reported similar abundances of ciliates to those measured in this study. During 1998 and 1999, Rollwagen-Bollens et al. (2006) observed Myrionecta rubra and tintinnid ciliates in all samples, with mean abundances of $\sim 1000$ $\mathrm{l}^{-1}$ for each category. In 2004 and 2005, Gifford et al. (2007) observed mean abundances of aloricate and tintinnid ciliates of $\sim 1500 \mathrm{l}^{-1}$ and $\sim 500 \mathrm{l}^{-1}$, respectively, at $\operatorname{Stn} 7$, with lower abundances of tintinnids in the winter $\left(\sim 10 \mathrm{l}^{-1}\right)$. We observed $M$. rubra in every month at almost every station in the LSZ at a mean abundance of $\sim 1000 \mathrm{l}^{-1}$ (range $0-8300 \mathrm{l}^{-1}$ ). Tintinnid ciliate abundance in this study averaged $\sim 1100 \mathrm{l}^{-1}$ (range $40-2600 \mathrm{l}^{-1}$ ), with the lowest values in winter (Fig. 2).

Dinoflagellates $(>20 \mu \mathrm{m})$ were not observed in any of our feeding experiments or in the abundance survey. Rollwagen-Bollens et al. (2006) and Gifford et al.
(2007) reported overall lower dinoflagellate abundances in the LSZ than any other types of microplankton. Additionally, dinoflagellate biomass was much lower than microzooplankton biomass (York et al. 2010) and total phytoplankton biomass (Lidström 2009) in the LSZ in 2006 to 2008.

\section{Feeding experiments}

Clam clearance rates on chl $a$ in this study (130 to $380 \mathrm{ml}$ ind $^{-1} \mathrm{~h}^{-1}$ ) were similar to those reported in previous studies (Table 7 ). Clearance rates on microphytoplankton (110 to $1050 \mathrm{ml}^{\text {ind }} \mathrm{d}^{-1} \mathrm{~h}^{-1}$; median $580 \mathrm{ml}$ ind $^{-1} \mathrm{~h}^{-1}$ ) and microzooplankton (170 to $970 \mathrm{ml} \mathrm{ind}^{-1}$ $\mathrm{h}^{-1}$; median $570 \mathrm{ml}$ ind $^{-1} \mathrm{~h}^{-1}$ ) calculated from cell counts were similar and generally higher than those on chl a. Additionally, clearance rates on bacterioplankton (Werner \& Hollibaugh 1993) were lower than those on chl a (their study) and on microzooplankton (this study), suggesting that Corbula amurensis has a lower clearance rate on smaller particles. Particle size influences filtration rates as gill ostia size controls the size range of particles that can be captured by bivalves (Riisgard 1988, Way 1989). The higher clearance rates observed in this study on microphytoplankton and microzooplankton than on chl a may be due to sizeselective feeding, since much of the chl $a$ in the SFE consists of cells less than 5 m (Kimmerer 2004, Wilkerson et al. 2006).

Clearance rates on microphytoplankton were more variable than on microzooplankton or chl $a$ and were sometimes negative (Table 5). All microphytoplankton were counted as individuals but some (i.e. Thalassiosira spp. and Leptocylindrus danicus) are chainforming diatoms. The strength of the cell-to-cell connections or length of the diatom chains in situ may influence capture by clams; however, this could not be examined directly using the individual cell counts.

The highest clearance rates on microzooplankton were on the aloricate ciliate Myrionecta rubra. Apparent food selectivity by a clam may occur through the interaction of swimming behavior of the prey with the incurrent and excurrent flows of the clam siphons, through size selectivity (either pre-capture by active rejection by the clam or post-capture), or through active post-capture rejection. $M$. rubra's high swimming speeds (Lindholm 1985) may increase the rate of encounters with potential predators and therefore lead to higher consumption rates (and clearance rates) by predators. Clearance rates by Corbula amurensis on tintinnid ciliates were lower than on aloricate ciliates, including $M$. rubra. The lower swimming speeds of tintinnid ciliates compared to aloricate ciliates and dif- 
ferences in swimming behavior may affect their encounter rates with clams (Capriulo et al. 1982).

Clearance rates of Corbula amurensis on cyclopoid copepod nauplii (Limnoithona tetraspina) were lower than rates observed for all other prey categories (Table 5). Kimmerer et al. (1994) also reported low clearance rates for $C$. amurensis feeding on calanoid copepod nauplii (Table 7). Copepod nauplii have been observed to actively escape incurrent plumes of both C. amurensis (W.J. Kimmerer unpubl. data) and mussel (Jonsson et al. 2009) siphons. These reported escape responses may contribute to the lower clearance rates of bivalves on nauplii. Copepod nauplii, while not very abundant, were the largest prey organisms examined in this study and contained the most carbon per individual. As a result, ingestion of nauplii had the potential to contribute significantly to the diet of clams if nauplii were actually ingested and fully assimilated as shown in Davenport el al. (2000).

Bivalves reject unwanted particles through the production and ejection of pseudofeces (Beninger \& St. Jean 1997), and prey, particularly tintinnd ciliates, may have been rejected by clams and entrained in pseudofeces. The equations used to calculate clearance rates in this study do not distinguish between particles that are ingested and those rejected in pseudofeces, since neither is assumed to reappear in the plankton. As a result, ingestion rates calculated from these clearance rates may be overestimates of what is actually available for assimilation. Additionally, ingestion rates reported in this study do not take into account assimilation efficiency, which has been observed to differ among prey types (Werner \& Hollibaugh 1993). This may affect the contributions of various prey to the growth of clams.

\section{Population estimates}

Fractional loss rates of microzooplankton (Fig. 3) varied seasonally with clam biomass and station depth. The high Corbula amurensis biomass (16 $\mathrm{g} \mathrm{AFDW} \mathrm{m}^{-2}$ ) in the channel during summer, combined with the measured clearance rates $\left(=0.55 \mathrm{l}\right.$ ind $^{-1} \mathrm{~h}^{-1} ; 34 \mathrm{lg}$ $\mathrm{AFDW}^{-1} \mathrm{~h}^{-1}$ ) on microzooplankton, indicates the potential for $C$. amurensis to clear a mean of $50 \%$ of the water column $\mathrm{d}^{-1}$ of microplankton at channel stations. In the shoals, the calculated mean water column turnover is 80 to $90 \% \mathrm{~d}^{-1}$. A Suisun Bay-wide (including both the channel and shoals) average depth of $\sim 5 \mathrm{~m}$ gives a calculated maximum water column turnover of $\sim 60 \% \mathrm{~d}^{-1}$. However, these calculations do not take into account that benthic boundary layers may reduce the availability of prey to the benthos (Jones et al. 2009) and that clams do not filter water $100 \%$ of the time. As a result, the reported fractional loss rates likely overestimate clam clearance rates at individual stations.

The fractional loss rates of microzooplankton suggest that the impact of Corbula amurensis on plankton extends from phytoplankton to protistan microzooplankton, particularly ciliates. Population growth rates determined in the LSZ during 2006 to 2008 were -16 to $27 \% \mathrm{~d}^{-1}$ for tintinnid ciliates and -111 to $41 \% \mathrm{~d}^{-1}$ for Myrionecta rubra (J. York pers. comm.). If clam consumption in Suisun Bay is as high as $60 \% \mathrm{~d}^{-1}$ then a subsidy of ciliates is required from the more saline regions downstream via dispersion in order to maintain ciliate populations in this region. These estimates of fractional loss rates support previous studies attributing declines in pelagic production to grazing by C. amurensis (Alpine \& Cloern 1992, Kimmerer et al. 1994, Jassby et al. 2002, Kimmerer 2006).

The ingestion of phytoplankton carbon was higher than the ingestion of microzooplankton carbon in most cases (Fig. 4), and no seasonal trends were observed in the relative proportions of phytoplankton carbon to microzooplankton carbon consumed. The mean ingestion of microzooplankton was $130 \mu \mathrm{g} \mathrm{C}$ ind $^{-1} \mathrm{~d}^{-1}$ (Fig. 4). Using an average AFDW of $0.016 \mathrm{~g}$ per clam and assuming carbon is $41 \%$ of AFDW (Cloern et al. 1993), each clam in this study consumed $<1.6 \%$ of its body carbon per day as microzooplankton. Mean ingestion of chl a as carbon was equivalent to $\sim 300 \mu \mathrm{g}$ $\mathrm{C}_{\text {ind }} \mathrm{d}^{-1} \mathrm{~d}^{-1}$ (Fig. 4), approximately $4.5 \%$ of each clams' body carbon per day as chl a.

Oxygen consumption, when represented in units of carbon, can be used to calculate the carbon requirement for metabolism (Ikeda et al. 2000). Paganini et al. (2010) reported respiration rates of $34 \mu \mathrm{mol} \mathrm{O} \mathrm{O}_{2} \mathrm{~g}$ dry $\mathrm{wt}^{-1} \mathrm{~h}^{-1}$ for Corbula amurensis. Using a respiratory quotient of 0.61 for Corbula gibba (Holmes \& Miller 2006) and this study's proxy for estimating dry weight

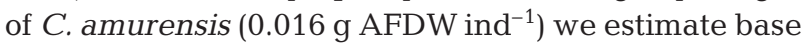
metabolic carbon demand per individual clam as $95 \mu \mathrm{g}$ $\mathrm{C}$ ind $\mathrm{d}^{-1} \mathrm{~d}^{-1}$. Thus, $C$. amurensis could meet its base metabolic carbon demand by ingesting microzooplankton alone.

Previous studies of bivalve grazing have focused primarily on phytoplankton and mesozooplankton consumption (Riisgard 1988, Hebert et al. 1991, Cahoon \& Owen 1996, Lehane \& Davenport 2002). The observed consumption of microzooplankton by Corbula amurensis suggests that these studies may underestimate the impact of bivalves on aquatic food webs. Additionally, the ability of $C$. amurensis to utilize microzooplankton as a carbon source may contribute to its success in the SFE.

In the future, studies assessing the impacts of benthic grazing on the overlying water column should include all planktonic functional groups including bac- 
teria, phytoplankton, and protistan and metazoan microzooplankton. Apparent changes in the abundance and size distribution of tintinnid ciliates suggest that ciliate biomass has declined following the introduction of Corbula amurensis. This seems likely given the decline in primary productivity of this region (Alpine \& Cloern 1992, Jassby et al. 2002) and the high clearance rate of clams on ciliates (this study).

Large-scale changes in food web dynamics can occur as a result of an invasion by a single species (Petersen et al. 2008). The introduction of the suspension feeding clam Mya arenaria and the zebra mussel Dreissena polymorpha serve as important examples of these kinds of ecosystem transformations (Petersen et al. 2008, Higgins \& Vander Zanden 2010). Rapid filter feeding by benthic bivalves can have devastating 'top down' effects on cladoceran, copepod, and rotifer populations (Higgins \& Vander Zanden 2010). Information on the contribution of bivalve grazing to mortality rates of all functional groups will help researchers understand the full role of bivalves in aquatic systems and will allow for better management of systems impacted by bivalve invasions.

Acknowledgements. We thank T. Ignoffo and A. Slaughter for their help in the laboratory and for their comments on an earlier draft. J. York provided assistance with microzooplankton identification and contributed microzooplankton growth rate data. S. Foster, F. Parchaso, C. Phillips, and T. Schraga assisted in the field along with Captain B. Richards and Chief Engineer S. Conard. K. Boyer, J. Cloern and F. Parchaso also provided comments on the manuscript. This research was funded by CALFED Science Program Grant SCI-05-C107.

\section{LITERATURE CITED}

Alpine AE, Cloern JE (1992) Trophic interactions and direct physical effects control phytoplankton biomass and production in an estuary. Limnol Oceanogr 37:946-955

Ambler JW, Cloern JE, Hutchinson A (1985) Seasonal cycles of zooplankton from San Francisco Bay. Hydrobiologia 129:177-197

Baldwin BS, Newell RIE (1991) Omnivorous feeding by planktotrophic larvae of the eastern oyster Crassostrea virginica. Mar Ecol Prog Ser 78:285-301

Beninger PG, St Jean SD (1997) The role of mucus in particle processing by suspension-feeding marine bivalves: unifying principles. Mar Biol 129:389-397

Bennet WA (2005) Critical assessment of the delta smelt population in the San Francisco Estuary, California. San Francisco Estuary Watershed Sci 3(2). Available at http:// esholarship.org/uc/item/0725n5vk\#

Bouley P, Kimmerer WJ (2006) Ecology of a highly abundant, introduced cyclopoid copepod in a temperate estuary. Mar Ecol Prog Ser 324:219-228

Cahoon LB, Owen DA (1996) Can suspension feeding by bivalves regulate phytoplankton biomass in Lake Waccamaw, North Carolina? Hydrobiologia 325:193-200

Capriulo GM, Gold K, Okubo A (1982) Evolution of the lorica in tintinnids: a possible selective advantage. Ann Inst Oceanogr Paris (Nouv Ser) 58:319-324
Carlton JT, Thompson JK, Schemel LE, Nichols FH (1990) Remarkable invasion of San Francisco Bay (California, USA) by the Asian clam Potamocorbula amurensis. I. Introduction and dispersal. Mar Ecol Prog Ser 66:81-94

Claessens M, Prast M (2008) Concentration of fixed plankton samples via settling: How long is long enough? J Plankton Res 30:57-64

Cloern JE (1982) Does the benthos control phytoplankton biomass in South San Francisco Bay? Mar Ecol Prog Ser 9: 191-202

Cloern JE, Canuel EA, Wienke SM (1993) Particulate organic matter in the San Francisco Bay estuary, California, chemical indicators of its origin and assimilation into the benthic food web: US Geological Survey Open-File Report 93-146

Coan EV (2002) The eastern Pacific recent species of the Corbulidae (Bivalvia). Malacologia 44:47-105

Cole BE, Thompson JK, Cloern JE (1992) Measurement of filtration rates by infaunal bivalves in a recirculating flume. Mar Biol 113:219-225

Crisp DJ (1971) Energy flow measurements. In: Holme NA, McIntyre AD (eds.) Methods for the study of marine benthos. IBP Handbook No. 16, Blackwell, Oxford, p 197-279

Dame R (1996) Ecology of marine bivalves: an ecosystem approach. In: Petralia P (ed) CRC Marine Science Series. CRC Press, Boca Raton, FL

Dame R, Zingmark R, Stevenson H, Nelson D (1980) Filter feeder coupling between the water column and benthic subsystem. In: Kennedy VS (ed) Estuarine perspectives. Academic Press, New York, NY, p 521-526

> Davenport J, Smith RJJW, Packer M (2000) Mussels mytilus edulis: Significant consumers and destroyers of mesozooplankton. Mar Ecol Prog Ser 198:131-137

Fenchel T (1982) Ecology of heterotrophic microflagellates. IV. Quantitative occurrence and importance as bacterial consumers. Mar Ecol Prog Ser 9:35-42

Feyrer F, Herbold B, Matern SA, Moyle PB (2003) Dietary shifts in a stressed fish assemblage: Consequences of a bivalve invasion in the San Francisco Estuary. Environ Biol Fishes 67:277-288

Frost BW (1972) Effects of size and concentration of food particles on feeding behavior of marine planktonic copepod Calanus Pacificus. Limnol Oceanogr 17:805-815

Gelman A, Chew GL, Shnaidman M (2004) Bayesian analysis of serial dilution assays. Biometrics 60:407-417

Gifford SM, Rollwagen-Bollens G, Bollens SM (2007) Mesozooplankton omnivory in the upper San Francisco estuary. Mar Ecol Prog Ser 348:33-46

- Goldman JC, Caron DA (1985) Experimental studies on an omnivorous microflagellate-implications for grazing and nutrient regeneration in the marine microbial food-chain. Deep-Sea Res 32:899-915

> Goldman JC, Caron DA, Andersen OK, Dennett MR (1985) Nutrient cycling in a microflagellate food chain. I. Nitrogen dynamics. Mar Ecol Prog Ser 24:231-242

Gould AL, Kimmerer WJ (2010) Development, growth, and reproduction of the cyclopoid copepod Limnoithona tetraspina in the upper San Francisco Estuary. Mar Ecol Prog Ser 412:163-177

Hebert PDN, Wilson CC, Murdoch MH, Lazar R (1991) Demography and ecological impacts of the invading mollusc Dreissena polymorpha. Can J Zool 69:405-409

- Higgins SN, Vander Zanden MJ (2010) What a difference a species makes: a meta-analysis of dreissenid mussel impacts on freshwater ecosystems. Ecol Monogr 80:179-196

> Holmes SP, Miller N (2006) Aspects of the ecology and population genetics of the bivalve Corbula gibba. Mar Ecol Prog Ser 315:129-140

Ikeda T, Torres JJ, Hernández-León S, Geiger SP (2000) 
Metabolism. In: Harris RP, Wiebe PH, Lenz J, Skjoldal HR, Huntley M (eds) Zooplankton methodology manual. Academic Press, London, p 455-532

Jassby AD, Cloern JE, Cole BE (2002) Annual primary production: patterns and mechanisms of change in a nutrientrich tidal estuary. Limnol Oceanogr 47:698-712

> Jones NL, Thompson JK, Arrigo KR, Monismith SG (2009) Hydrodynamic control of phytoplankton loss to the benthos in an estuarine environment. Limnol Oceanogr 54: 952-969

> Jonsson A, Nielsen TG, Hrubenja I, Maar M, Petersen JK (2009) Eating your competitor: functional triangle between turbulence, copepod escape behavior and predation from mussels. Mar Ecol Prog Ser 376:143-151

Kimmerer WJ (2004) Open water processes of the San Francisco Estuary: from physical forcing to biological responses. San Francisco Estuary Watershed Sci 2(1), Article 1

Kimmerer WJ (2006) Response of anchovies dampens effects of the invasive bivalve Corbula amurensis on the San Francisco Estuary foodweb. Mar Ecol Prog Ser 324:207-218

Kimmerer WJ, Gartside E, Orsi JJ (1994) Predation by an introduced clam as the likely cause of substantial declines in zooplankton of San Francisco Bay. Mar Ecol Prog Ser 113: 81-93

Lehane C, Davenport J (2002) Ingestion of mesozooplankton by three species of bivalve; Mytilus edulis, Cerastoderma edule and Aequipecten opercularis. J Mar Biol Assoc UK 82:615-619

Lidström UE 2009. Primary production, biomass and species composition of phytoplankton in the low salinity zone of the northern San Francisco Estuary. MS Thesis, San Francisco State University.

Lindholm T (1985) Mesodinium rubrum-a unique photosynthetic ciliate. Adv Aquat Microbiol 3:1-48

Lund JWG, Kipling C, Le Cren ED (1958) The inverted microscope method of estimating algal numbers and the statistical basis of estimations by counting. Hydrobiologia 11: 143-170

Lunn DJ, Thomas A, Best N, Spiegelhalter D (2000) WinBUGS -A Bayesian modelling framework: Concepts, structure, and extensibility. Stat Comput 10:325-337

MacIsaac HJ, Johannsson OE, Ye J, Sprules WG, Leach JH, McCorquodale JA, Grigorovich IA (1999) Filtering impacts of an introduced bivalve (Dreissena polymorpha) in a shallow lake: application of a hydrodynamic model. Ecosystems 2:338-350

McManus GB, Fuhrman JA (1988) Control of marine bacterioplankton populations: measurement and significance of grazing. Hydrobiologia 159:51-62

Menden-Deuer S, Lessard EJ (2000) Carbon to volume relationships for dinoflagellates, diatoms, and other protist plankton. Limnol Oceanogr 45:569-579

Miehls ALJ, Mason DM, Frank KA, Krause AE, Peacor SD, Taylor WW (2009) Invasive species impacts on ecosystem structure and function: a comparison of Oneida Lake, New York, USA, before and after zebra mussel invasion. Ecol Modell 220:3194-3209

Nichols FH, Thompson JK, Schemel LE (1990) Remarkable invasion of San Francisco Bay (California, USA) by the Asian clam Potamocorbula amurensis. II. Displacement of a former community. Mar Ecol Prog Ser 66:95-101

Nicolini MH, Penry DL (2000) Spawning, fertilization, and larval development of Potamocorbula amurensis (Mollusca: Bivalvia) from San Francisco Bay, California. Pac Sci 54: $377-388$

Editorial responsibility: Antonio Bode, A Coruña, Spain
Norén F, Haamer J, Lindahl O (1999) Changes in the plankton community passing a Mytilus edulis mussel bed. Mar Ecol Prog Ser 191:187-194

Officer C, Smayda T, Mann R (1982) Benthic filter feeding: a natural eutrophication control. Mar Ecol Prog Ser 9: 203-210

Orsi JJ, Mecum WL (1996) Food limitation as the probable cause of a long-term decline in the abundance of Neomysis mercedis the opossum shrimp in the Sacramento-San Joaquin estuary. In: Hollibaugh JT (ed) San Francisco Bay: the ecosystem. AAAS, San Francisco, California, p 375-401

> Pace ML, Findlay SEG, Fischer D (1998) Effects of an invasive bivalve on the zooplankton community of the Hudson River. Freshw Biol 39:103-116

Paganini A, Kimmerer WJ, Stillman JH (2010) Metabolic responses to environmental salinity in the invasive clam Corbula amurensis. Aquat Biol 11:139-147

Petersen JK, Hansen JW, Laursen MB, Clausen P, Cartensen J, Conley DJ (2008) Regime shift in a coastal marine ecosystem. Ecol Appl 18:497-510

Putt M, Stoecker DK (1989) An experimentally determined carbon:volume ratio for marine 'oligotrichous' ciliates from estuarine and coastal waters. Limnol Oceanogr 34: 1097-1103

Riisgård HU (1988) Efficiency of particle retention and filtration rate in 6 species of Northeast American bivalves. Mar Ecol Prog Ser 45:217-223

Rollwagen-Bollens GC, Bollens SM, Penry DL (2006) Vertical distribution of micro- and nanoplankton in the San Francisco Estuary in relation to hydrography and predators. Aquat Microb Ecol 44:143-163

Sommer T, Armor C, Baxter R, Breuer R and others (2007) The collapse of pelagic fishes in the upper San Francisco Estuary. Fisheries 32:270-277

Stoecker DK, Gifford DJ, Putt M (1994) Preservation of marine planktonic ciliates: losses and cell shrinkage during fixation. Mar Ecol Prog Ser 110:293-299

Thompson JK (2005) One estuary, one invasion, two responses: phytoplankton and benthic community dynamics determine the effect of an estuarine invasive suspension feeder. In: Olenin S, Dame R (eds) The comparative roles of suspension feeders in ecosystems. Springer, Amsterdam, p 291-316

Throndsen J (1978) Preservation and storage. In: Sournia A (ed) Phytoplankton manual. Unesco, Paris, p 69-74

- Vaughn CC, Hakenkamp CC (2001) The functional role of burrowing bivalves in freshwater ecosystems. Freshw Biol 46:1431-1446

Verity PG, Langdon C (1984) Relationships between lorica volume, carbon, nitrogen, and ATP content of tintinnids in Narragansett Bay. J Plankton Res 6:859-868

Way CM (1989) Dynamics of filter-feeding in Musculium transversum (Bivalvia:Sphaeriidae). J N Am Benthol Soc 8:243-249

Werner I, Hollibaugh JT (1993) Potamocorbula amurensis: comparison of clearance rates and assimilation efficiencies for phytoplankton and bacterioplankton. Limnol Oceanogr 38:949-964

Wilkerson FP, Dugdale RC, Hogue VE, Marchi A (2006) Phytoplankton blooms and nitrogen productivity in San Francisco Bay. Estuaries Coasts 29:401-416

York JK, Costas BA, McManus GB (2010) Microzooplankton grazing in green water - results from two contrasting estuaries. Estuaries Coasts 33:373-385

Submitted: December 1, 2010; Accepted: February 18, 2011

Proofs received from author(s): May 12, 2011 